\title{
Morphological findings in the tracheal epithelium of dogs exposed to the inhalation of poorly conditioned gases under use of an endotracheal tube or laryngeal mask airway ${ }^{1}$
}

\author{
Alterações morfológicas no epitélio traqueal de cães expostos à inalação de gases pouco \\ condicionados, sob ventilação com tubo traqueal ou máscara laríngea
}

\begin{abstract}
Norimar Hernandes Dias', José Reinaldo Cerqueira Braz ${ }^{\mathrm{II}}$, Júlio DefaveriII, Lídia Raquel Carvalho ${ }^{\mathrm{IV}}$, Regina Helena Garcia Martins $^{\mathrm{V}}$

${ }^{1}$ Research performed at Experimental Anesthesia Laboratory, Botucatu Medical School, Sao Paulo State University (UNESP), Brazil. ${ }^{I} \mathrm{PhD}$, Associate Professor, Department of Otorhinolaryngology, Ophthalmology and Head and Neck Surgery. Botucatu Medical School, UNESP, Sao Paulo, Brazil Conception, design and scientific content of the study. Analysis and interpretation of data, manuscript writing and critical revision. "I Full Professor, Department of Anaesthesiology, Botucatu Medical School, UNESP, Sao Paulo, Brazil. Responsible for conception of the study and critical revision.

III Full Professor, Department of Pathology, Botucatu Medical School, UNESP, Sao Paulo, Brazil. Histophatological analysis.

${ }^{\text {Iv }} \mathrm{PhD}$, Associate Professor, Department of Biostatistics. Institute of Biosciences, UNESP, Sao Paulo, Brazil. Statistical analysis.

${ }^{v}$ Full Professor, Department of Otorhinolaryngology, Ophthalmology and Head and Neck Surgery, Botucatu Medical School, UNESP, Sao Paulo, Brazil. Responsible for conception of the study and critical revision.
\end{abstract}

\begin{abstract}
PURPOSE: To study morphological findings in the tracheal epithelium of dogs exposed to the inhalation of poorly conditioned gases under use of an endotracheal tube (ET) or laryngeal mask airway (LMA).

METHODS: Twelve dogs randomly were allocated to two groups: ET group (n-6) and LMA group (n-6), anaesthetized and mechanically ventilated, without $\mathrm{CO}_{2}$ reabsorption. Haemodynamic and ventilatory parameters, tympanic temperature, temperature, relative and absolute humidity of the ambient and inhaled gases were analyzed during three hours. The animals were submitted to euthanasia and biopsies were carried out along the tracheal segment to morphological study. Three healthy dogs were used to morphological control. RESULTS: Inhaled gas temperature was maintained between $24^{\circ} \mathrm{C}$ and $26^{\circ} \mathrm{C}$, relative humidity between $10 \%$ and $12 \%$, and absolute humidity between $2-3 \mathrm{mg} \mathrm{H}$ O.L. $\mathrm{L}^{-1}$ with no significant differences between groups. In both groups, histological analysis showed epithelial inflammation and congestion in the corion and scanning electron microscopy showed ciliary grouping and disorganization. Transmission electron microscopy showed higher alterations in ET group than LMA group as widening of cell junctions, ciliary disorientation, cytoplasmic vacuolization, nuclear abnormalities, picnosis and chromatin condensation.
\end{abstract}

CONCLUSION: LMA determined less pronounced changes in the tracheal epithelium in dogs exposed to the inhalation of poorly conditioned gases.

Key words: Larynx. Trachea. Laryngeal Masks. Intubation, Intratracheal. Morphology. Dogs.

\section{RESUMO}

OBJETIVO: Avaliar as alterações morfológicas no epitélio traqueal de cães expostos à inalação de gases pouco condicionados, sob ventilação com tubo traqueal (TT) ou máscara laríngea (ML).

MÉTODOS: Doze cães adultos foram divididos aleatoriamente em dois grupos: grupo TT (n-6) e grupo ML (n-6), submetidos à anestesia venosa e ventilação mecânica, em sistema sem reabsorção de $\mathrm{CO}_{2}$. Foram registrados parâmetros hemodinâmicos e ventilatórios, temperatura timpânica, temperatura, umidade relativa e absoluta do ar ambiente e dos gases inalados durante 3 horas. Ao término do experimento, os animais foram submetidos a eutanásia e realizadas biópsias ao longo do segmento traqueal para estudo morfológico. Três cães saudáveis foram utilizados para controle morfológico.

RESULTADOS: A temperatura dos gases inalados manteve-se entre $24^{\circ} \mathrm{C}$ e $26^{\circ} \mathrm{C}$, a umidade relativa entre $10 \%$ e $12 \%$, e umidade absoluta entre 2 - $3 \mathrm{mg} \mathrm{H}$ O.L $\mathrm{m}^{-1}$ sem diferença significativa entre os grupos. Em ambos os grupos a análise histológica evidenciou processo inflamatório epitelial e congestão no córion, e a microscopia eletrônica de varredura mostrou agrupamento e desorganização ciliar. A microscopia eletrônica de transmissão detectou maiores alterações no grupo TT do que no ML, como alargamento das junções intercelulares, desorientação ciliar, vacuolização citoplasmática, alterações nucleares como pcinose e condensação da cromatina. CONCLUSÃO: A máscara laríngea determinou alterações menos pronunciadas no epitélio traqueal de cães expostos à inalação de gases pouco condicionados.

Descritores: Laringe. Traquéia. Máscaras Laríngeas. Intubação Intratraqueal. Morfologia. Cães. 


\section{Introduction}

During respiration, inspired air gains approximately $75 \%$ of heat and humidity as it passes through the nose and rhinopharynx, due to the high vascularization and a large contact surface $^{1}$. In the remainder airway segments (pharynx, larynx, trachea and bronchi), the conditioning process is completed. Nasal obstruction, tracheotomy, intubation or laryngectomy are conditions that the passage of inspired air through the nasal cavities is impaired requiring high participation of remaining airway segments in the humidity and heat exchanges ${ }^{2}$.

The characteristics of the respiratory epithelium are important in the conditioning of inhaled air. The respiratory epithelium is sensitive to the action of inspired irritative factors. Experimental researches have reported respiratory epithelial injuries of varying degrees in consequence of the inhalation of cold and dry gases as decreased mucociliary clearance; increased mucus viscosity and dryness; ciliary disorganization, grouping or devastation; mucosa erosion, ulceration and necrosis; inflammation and even metaplasia of the tracheal epithelium in chronic processes ${ }^{3-5}$.

In a previous experiment carried by our group, the real participation of the laryngotracheal segment in air conditioning was quantitatively demonstrated. Significantly, higher tracheal air absolute humidity was observed in dogs exposed to the inhalation of high fresh gas flow with inadequate temperature and humidity through a laryngeal mask airway (LMA) (23 mg $\left.\mathrm{H}_{2} \mathrm{O} . \mathrm{L}^{-1}\right)$ than in those ventilated through an endotracheal tube (ET) $\left(14 \mathrm{mg} \mathrm{H}_{2} \mathrm{O} . \mathrm{L}^{-1}\right)$. These satisfactory results were attributed to the positioning of the LMA, which is placed higher on the airway (supraglottic region) keeping the laryngotracheal segment free from contact with the inspired gases, and allowing its exposure to heat and humidity exchanges ${ }^{6}$. However, the performance of tracheotomy, necessary for the introduction of a thermohygrometer to monitor the temperature and humidity of the tracheal gases, did not allow morphological analyses of the tracheal epithelium. Thus, in order to complement our previous investigation, this study aimed at describing the morphological particularities of the tracheal epithelium in dogs exposed to the inhalation of gases with low temperature and humidity to confirm the advantages of using a LMA in relation to ET.

\section{Methods}

The study was approved by the Animal Research Ethics Committee of Botucatu Medical School - UNESP. Twelve adult mixed-breed male dogs, weighing 15-27 kg, underwent venous anaesthesia with sodium pentobarbital and with mechanical ventilation through a system without $\mathrm{CO}_{2}$ reabsorption for three hours. The animals were randomly allocated into the two following groups, according to the method used for airway maintenance: ET group (endotracheal group; $\mathrm{n}$ - 6), using ET Portex no 8.5 (England) and LMA group (Laryngeal Mask Airway; n - 6), using LMA Classic TM n 4 (Singapore). A biomonitor (AS3, Datex Engstron) was used for monitoring and recording temperature, ventilation, oxygenation and haemodynamic variables.

After 12 hours of fasting, a 20-G catheter was placed in the femoral vein. The dogs received a bolus injection of $25 \mathrm{mg} /$ $\mathrm{kg}$ pentobarbital, followed by intravenous infusion maintenance of $5 \mathrm{mg} / \mathrm{kg}$ per hour, and infusion of $5 \mathrm{~mL} / \mathrm{kg}$ per hour of lactated Ringer's solution for hydration, using a two channel infusion pump (Anne, Abbott). The animals were placed in dorsal recumbence with the head extended, and maintained under mechanical ventilation in a system without $\mathrm{CO}_{2}$ reabsorption with $3 \mathrm{~L} / \mathrm{min}$ ambient air and 2 L/min O2 (K. TAKAOKA, model 2600, Series Nikkei). Neuromuscular block was induced by alcuronium chloride at an initial dose of $0.2 \mathrm{mg} / \mathrm{kg}$, followed by maintenance doses of $0.06 \mathrm{mg} / \mathrm{kg}$ every 60 minutes. We used a tidal volume of 20 $\mathrm{mL} / \mathrm{kg}$ and a respiratory rate of $12-14$ breaths/min to maintain an end-tidal $\mathrm{CO}_{2}\left(\mathrm{PetCO}_{2}\right)$ concentrations at $4.66-5.33 \mathrm{kPa}$. The left femoral artery was cannulated with polyethylene catheter (P240) to measure mean arterial pressure. A three-lead electrocardiogram (DII lead) was installed and a pulse oximetry sensor was located on the animal's tongue. The temperature and relative humidity of the inspiratory gas were measured using an electronic digital thermo-hygrometer (hygrotermo 95, Gulton), connected by a $\mathrm{T}-$ placed between the inspiratory branch and ET or LMA. Absolute humidity was calculated from relative humidity and temperature according to a specific table. The formula used was:

$$
\mathrm{AH}=\mathrm{RH} . \mathrm{MH}
$$

in which $\mathrm{AH}=$ absolute humidity $\left(\mathrm{mg} \mathrm{H}_{2} \mathrm{O} \cdot \mathrm{L}^{-1}\right) ; \mathrm{RH}=$ relative humidity (percent); $\mathrm{MH}=$ maximum air humidity $\left(\mathrm{mg} \mathrm{H}_{2} \mathrm{O} . \mathrm{L}^{-1}\right)$ (specific table ${ }^{7}$ ).

Haemodynamic parameters (mean arterial pressure, heart rate), ventilatory parameters (respiratory rate, tidal volume, peripheral oxyhaemoglobin saturation $-\mathrm{SpO}_{2}, \mathrm{P}_{\mathrm{ET}} \mathrm{CO}_{2}$, inspiratory pressure), tympanic temperature, temperature and both relative and absolute humidity of the inhaled gases were measured after 10 minutes of mechanical ventilation installation, and at 60, 120 and 180 minutes afterwards. 
After three hours, the animals were euthanized by pentobarbital overdose. The laryngotracheobronchial segment was removed, and in ET group the tracheal tube was maintained to identify the exact position of its distal extremity. Biopsies measuring $0.5 \times 1 \mathrm{~cm}$ were performed below the $5^{\text {th }}$ tracheal ring in both groups, on the inner surface of the anterior portion of the trachea. Thus, the following sites of biopsies were pre determined: (PT - proximal trachea, MT - medial trachea and DT - distal trachea, Figure 1).

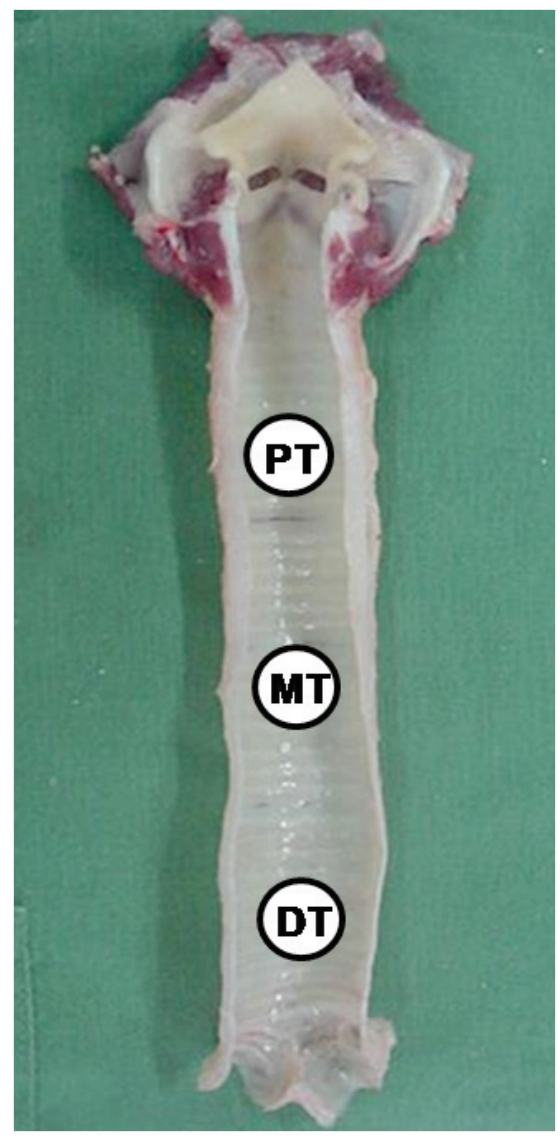

FIGURE 1 - Tracheal mucosa biopsy areas (PT - proximal trachea, MT - medial trachea, DT - distal trachea).

The fragments were examined under light and electron microscopy (scanning and transmission). The pathologist was blinded to the origin of the samples.

Three healthy male dogs were euthanized by pentobarbital overdose. The laryngotracheobronchial segments were removed and biopsies were done in the same areas to morphological control of light and electron microscopy.

\section{Light microscopy}

The histopathological analysis included the epithelium (erosion and inflammation), the basal membrane (normal or thickened), and the lamina propria (congestion, hemorrhage and inflammation). Histological parameters were quantified using a semiquantitative score: 0 (no alteration), 1 (mild alteration), 2 (moderate alteration) and 3 (intense alteration). For examination and photographic recording, a light microscope (Zeiss - Carl Zeiss do Brasil Ltda; Axiostar plus model) was used under different magnifications and images were captured by a digital camera.

\section{Scanning and transmission electron microscopy}

Tracheal mucosa biopsy samples $(1 \mathrm{x} 1 \mathrm{~cm})$ of the same sites examined under light microscopy (PT, MT and DT) were obtained from the animals of each group. Half of each fragment was examined under scanning electron microscopy (SEM) and the other under transmission electron microscopy (TEM). For SEM, the specimens were fixed in $2.5 \%$ glutaraldehyde for 12 hours, flushed in $0.1 \mathrm{M}$ phosphate buffer at $\mathrm{pH} 7.3$, fixed in a $1 \%$ osmium tetroxide solution for 1 hour, flushed in phosphate buffer, dehydrated in series in increasing solutions of 75\%-100\% alcohol, and dried in a critical point device (Balzers CPD-020) with liquid carbon dioxide. Subsequently, they were assembled in a metal base with silver glue, and covered with gold (15nm of gold) in a Balzers MED-010 device. Then they were visualized and photographed at increasing magnitudes under a scanning electron microscope (model QUANTA 200, FEI, Czech Republic). Each fragment was semiquantitatively scored as follows: $\mathbf{0}$ (no ciliary alteration, completely intact epithelium), 1 (focal ciliary grouping and/or disorientation), 2 (extensive ciliary grouping and/or disorientation, without epithelial ulceration), 3 (extensive ciliary rarefaction, without epithelial ulceration) and $\mathbf{4}$ (extensive ciliary rarefaction and epithelial ulceration).

For TEM, the specimens were fixed in $2.5 \%$ glutaraldehyde, flushed in $0.1 \mathrm{M}$ phosphate buffer, $\mathrm{pH} 7.3$, and added to $1 \%$ tannic acid in order to facilitate extracellular matrix visualization. Subsequently, they were sectioned into $3 \mathrm{~mm} \times 1 \mathrm{~mm}$ slices on pink dental wax, wetted in $2.5 \%$ glutaraldehyde fixing solution, fixed by $1 \%$ osmium acid and $0.1 \mathrm{M}$ phosphate buffer, $\mathrm{pH}$ 7.3 , dehydrated in an increasing series of acetone solution $(50 \%$, $70 \%, 90 \%$ and $100 \%$ ), and dipped in a mixture of acetone and araldite resin (Polysciences, Inc.). The fragments were removed from this mixture and embedded in an araldite resin block in an oven at $37^{\circ} \mathrm{C}$. Semi-fine $0.5-\mu \mathrm{m}$ sections were cut and dyed with 
a mixture of $1 \%$ methylene blue and 1\% Azur II. These semi-fine slices were examined under light microscopy and once again cut into ultra-fine (500) sections that were examined and photographed under a transmission electron microscope, frame by frame at increasing magnifications (model EM 301, Philips AG), using Eastman 5302 film and Kodabromide photographic paper. Each fragment was semiquantitatively scored as follows: $\mathbf{0}$ (epithelial cells of normal configuration), 1 (intercellular junction widening and/or presence of inflammatory cells, with normal basement membrane), 2 (intercellular junction widening and/or presence of inflammatory cells, cytoplasmic vacuolization, with normal basement membrane), 3 (cytoplasmic vacuolization with cellular/ nuclear polymorphism and abnormal basement membrane).

Unpaired t-test was used for the statistical analysis of differences in animal weight and length, while Fisher's test was used to evaluated gender differences. When variables were not normally distributed, the values measured at each time point within each group were compared using Friedman's nonparametric test, whereas values at each time point between groups were compared by the Mann-Whitney nonparametric test. Variables normally distributed were compared by ANOVA, followed by Tukey's test. Significance was set at $p<0.05$.

\section{Results}

There was no difference in dog mean weight $(\mathrm{ET}=19.7$ $\pm 4.7 \mathrm{~kg}, \mathrm{LMA}=17.5 \pm 3.2 \mathrm{~kg} ; p=0.37)$ and mean length between groups $(\mathrm{ET}=104.8 \pm 10.6 \mathrm{~cm}, \mathrm{LMA}=97.0 \pm 7.9 \mathrm{~cm} ; p=0.18)$. Haemodynamic and ventilation parameters remained constant over time, with no significant differences between groups $(p>0.05)$. Tympanic temperature was kept between $37^{\circ} \mathrm{C}$ and $38.5^{\circ} \mathrm{C}$, with no differences between groups $(p=0.69)$. Inhaled gas temperature was between $24^{\circ} \mathrm{C}$ and $26^{\circ} \mathrm{C}$ with no significant differences between groups $(p=0.46)$, relative humidity was maintained between $10 \%$ and $12 \%$, while absolute humidity was maintained between $2 \mathrm{mg}$ $\mathrm{H}_{2} \mathrm{O} . \mathrm{L}^{-1}$ and $3 \mathrm{mg} \mathrm{H}_{2} \mathrm{O} . \mathrm{L}^{-1}$ with no significant difference between groups ( $p=0.22$ and $p=0.62$, respectively).

\section{Morphological assessment}

The morphological analysis of all tracheal specimens of the control animals showed normal aspect. In light microscopy the pseudostratified columnar ciliated epithelium was composed by ciliated cells, goblet cells and basal cells. No edema, congestion or inflammation were identified in the lamina propria (Figure 2).

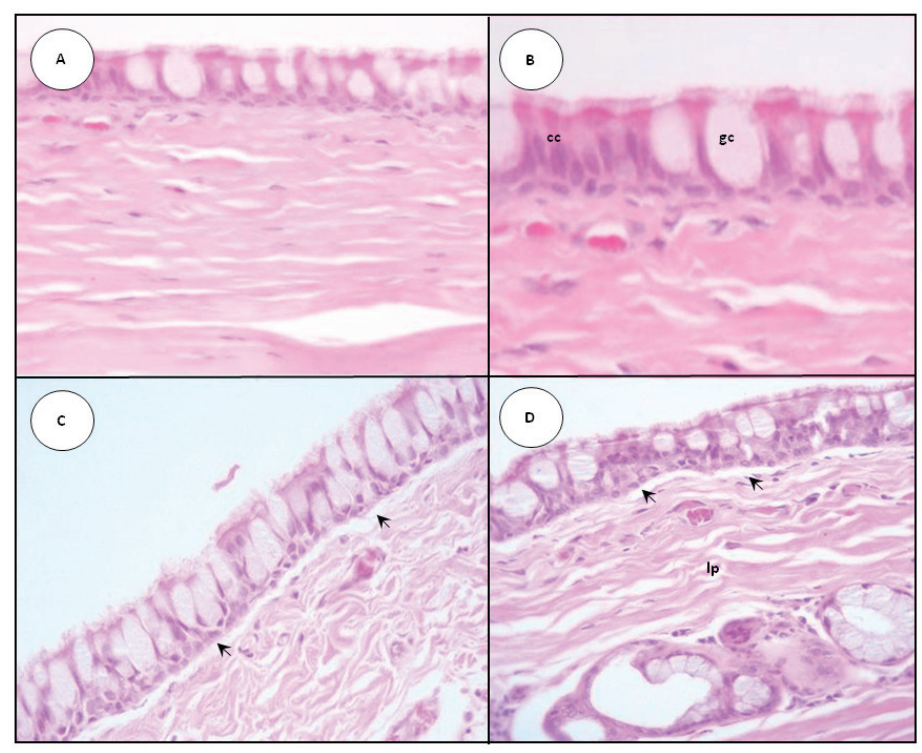

FIGURE 2 - Control dog. Proximal trachea. Pseudostratified columnar epithelium with ciliated cells (cc) and goblet cells (gc) (A and B). Delicate basement membrane (C and $\mathbf{D}$, arrows). Lamina propria (Ip) with collagen fibers and gland clusters (D). Light microscopy (H\&E), x40.

However, in the animals of ET and LMA groups, histological changes were observed in some areas that included acute inflammation, polymorphonuclear neutrophil infiltration in the epithelium, and congestion in the lamina propria (Figure 3).

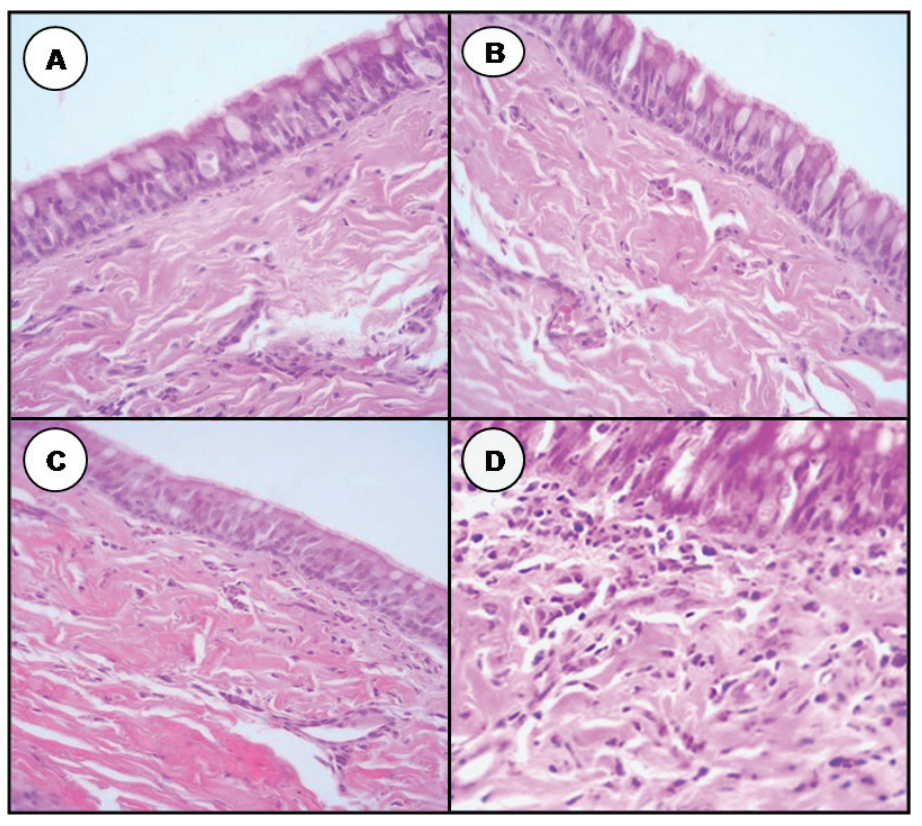

FIGURE 3 - Medial trachea. Mild PMN infiltrate in the lamina propria (A and $\mathbf{B}$; LMA group, $\mathrm{x} 40$ ); Moderate PMN infiltrate in the lamina propria (C and D; TT group, x40 e x60, respectively). Light microscopy (H\&E).

These findings were slightly more accentuated in ET 
group, though no statistical difference was reached $(p>0.05)$.

Scanning electron microscopy (SEM) showed abundant ciliated cells on tracheal epithelium of the control animals and goblet cells lied between them (Figure 4).

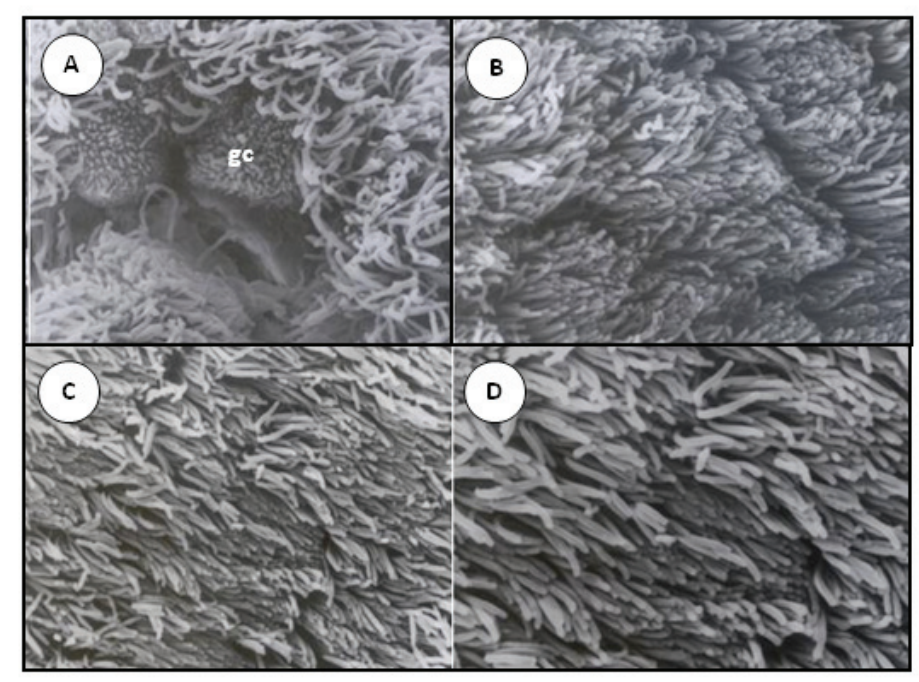

FIGURE 4 - Control dog. Distal trachea. Scanning electron microscopy showing goblet cells (gc) lie between ciliated cells (A, x 4,820), and abundance of the ciliated cells and normal cilia structure $(\mathbf{B}-\mathrm{x} 4,055$, C $-x$ 4,630 and $\mathbf{D}-\mathrm{x} 6,840)$.

In ET and LMA groups were observed ciliary grouping and disorganization, without difference between groups $(p=0.58)$ (Figure 5).

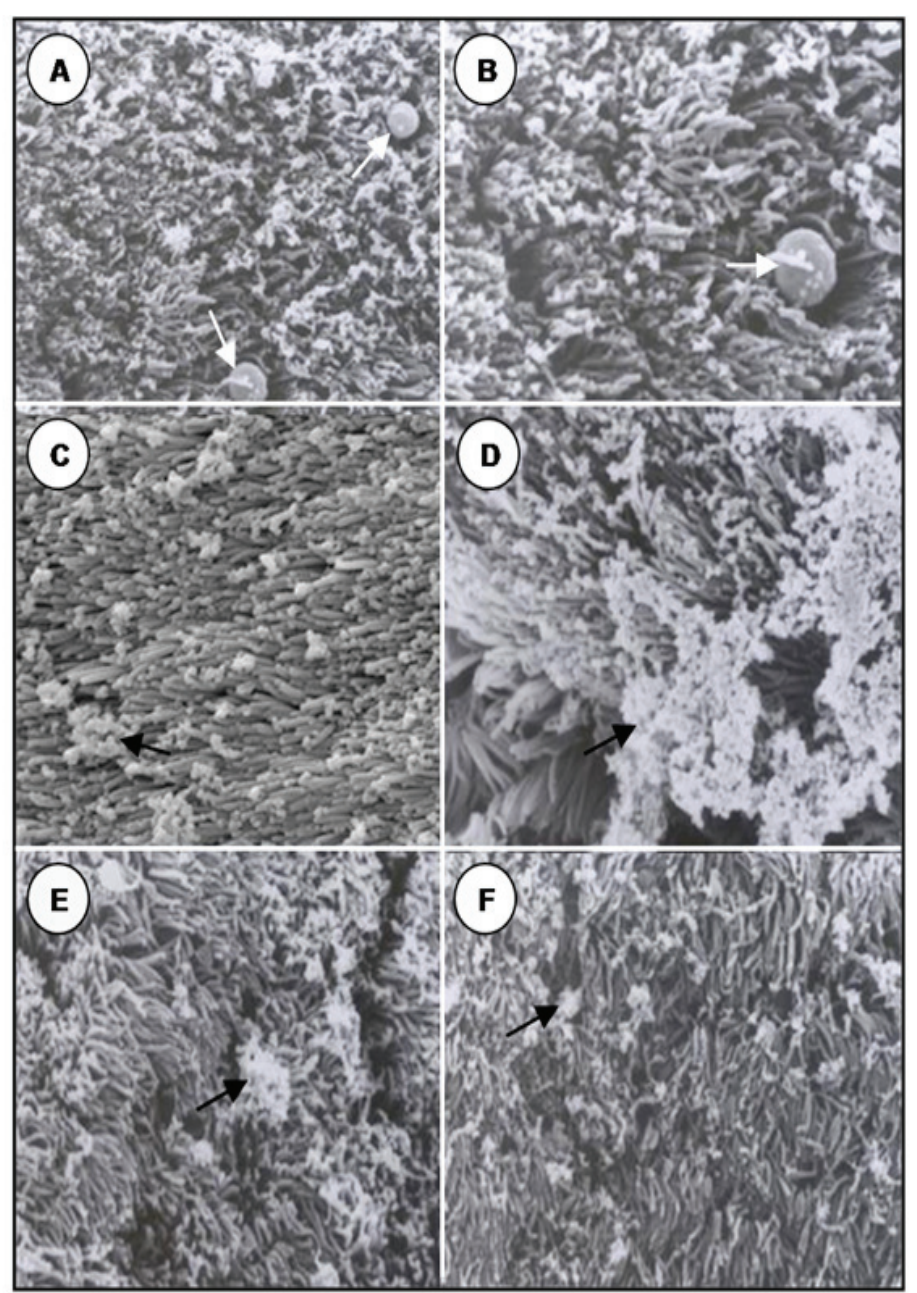

FIGURE 5 - Proximal tracheal epithelium (ET group). Scanning electron microscopy showing ciliary disorganization and disorientation on epithelial surface and mucus droplet (arrows) of normal aspect being expelled to the epithelial surface $(\mathbf{A}-\mathrm{x} 2,760 ; \mathbf{B}-\mathrm{x} 4,825)$; adhering cilia forming small groupings (arrows; $\mathbf{C}-\mathrm{x} 3,500$; $\mathbf{D}-\mathrm{x} 4,825$ ); more intense ciliary disorientation and grouping (arrows; $\mathbf{E}-\mathrm{x} 4,440 ; \mathbf{F}-\mathrm{x} 3,885$ ).

Transmission electron microscopy (TEM) demonstrated similar aspect with ciliated, goblet and basal cells. Numerous cilios could be identified on the apical portion of ciliated cells. Intracytoplasmatic organelles were disposed with a distinct polarity and a large nucleus occupying about half the cell volume. The goblet cells were filled with vesicles containing material of variable density. The cells are connected by desmosomes and interdigitations of the cell membrane (Figure 6). 


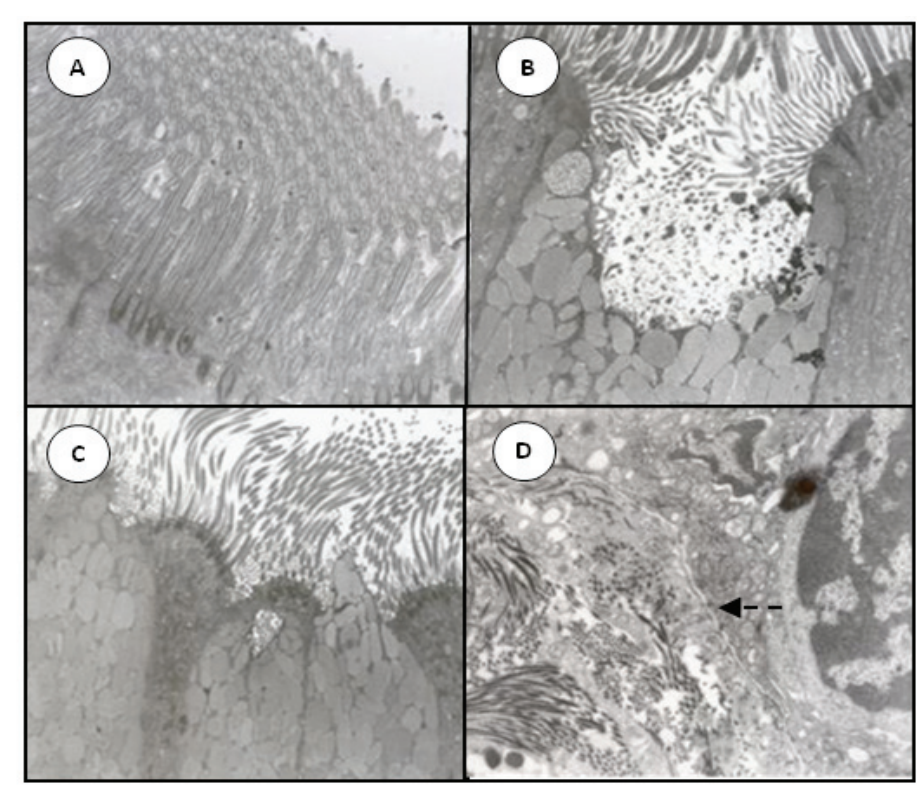

FIGURE 6 - Control dog. Medial trachea. Transmission electron microscopy showing abundance of the ciliated cells and normal aspect of the cilia (A - x 17,000); goblets cells and ciliated cells (B $-\mathrm{x} 13,250$ ; C $-\mathrm{x}$ 5,750); intact and continuous basement membrane (arrow; $\mathbf{D}-\mathrm{x}$ 17,000).

In ET and LMA groups, TEM demonstrated some important alterations, particularly among the dogs under ET ventilation $(p=0.01)$. These alterations included widening of cell junctions, ciliary disorientation, cytoplasmic vacuolization, nuclear abnormalities, picnosis and chromatin condensation (Figure 7).

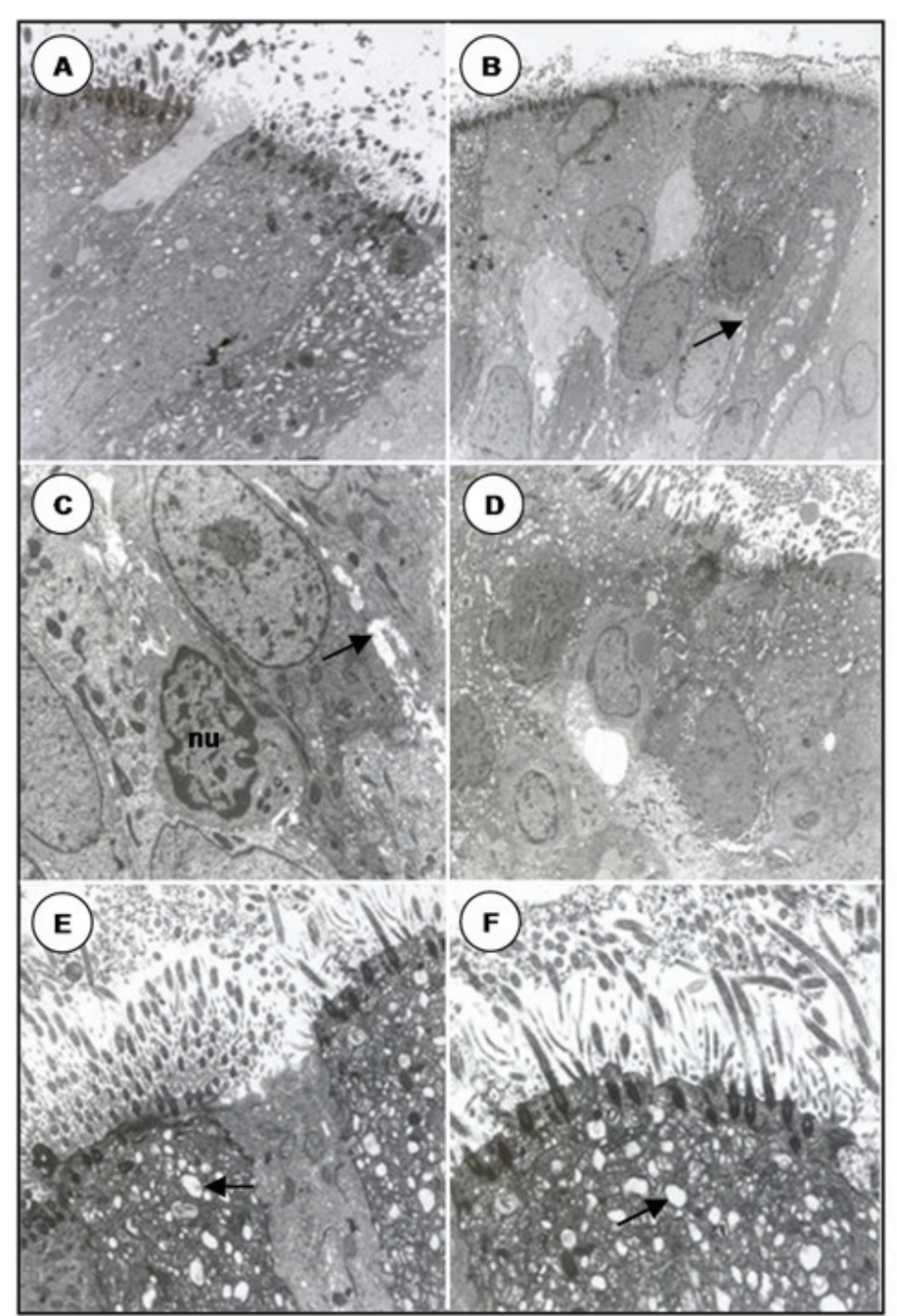

FIGURE 7 - Proximal tracheal epithelium (ET group). A - ciliary desorientation and rarefaction on epithelial surface; $\mathbf{B}, \mathbf{C}$ and $\mathbf{D}-$ cell junction widening (arrows), picnotic nucleus with condensed chromatin (nu); $\mathbf{E}$ and $\mathbf{F}$ - cytoplasmic vacuolozation (arrows), ciliary rarefaction and disorganization. TEM (A - 7.750X; B - 3.250X; C - 5.750X; D 7.750X; E-9.750X; F-13.250X).

Neither epithelial erosion nor disruptions in basement membrane integrity were observed in any of the groups.

\section{Discussion}

The main finding of this study was that ventilation via LMA gave less pronounced changes in the tracheal epithelium than ventilation via an ET in dogs exposed to the inhalation of poorly conditioned gases. Then, our study is the first one to demonstrate that the LMA seems to protect tracheal epithelium during inhalation of dry air. A system without $\mathrm{CO}_{2}$ reabsorption with high FGF was used in an attempt to reproduce the same methods employed in our previous experiment by keeping the humidity and heat of inspired air at low levels ${ }^{6}$. Some investigators 
have shown that high FGF has a reducing effect on humidity and temperature. Henriksson et al. ${ }^{8}$ assessed humidity and temperature at different gas flows $\left(<1 \mathrm{~L} \cdot \mathrm{min}^{-1}, 2 \mathrm{~L} \cdot \mathrm{min}^{-1}\right.$, and $\left.5 \mathrm{~L} \cdot \mathrm{min}^{-1}\right)$, and found lower heat and humidity levels at a FGF of $5 \mathrm{~L} \cdot \mathrm{min}^{-1}$, which was also used in our study.

The dog trachea has about forty cartilaginous rings that are mostly located in the cervical region facilitating access to biopsy sites. In this study, morphological evaluation was performed on biopsy fragments of the proximal, medial and distal trachea, located beneath the distal edge of the tube, avoiding the tracheal areas where there was contact with the cuff.

Damages to the respiratory epithelium secondary to the inhalation of poorly conditioned gases via an ET have been reported in several experimental studies $3,9,10$. During anaesthesia, the lowest absolute humidity of the inspired gases is recommended to be 23 $\mathrm{mg} \mathrm{H}_{2} \mathrm{O} . \mathrm{L}^{-1}$ to reduce the risk of dehydration of the respiratory $\operatorname{tract}^{11}$. It is not infrequent the inhalation of gases with inadequate humidity during anaesthesia, even if low FGF (1 L.min $\left.{ }^{-1}\right)$ is utilized $^{12}$. Thus, the levels of inspired gas humidity used in this study were lower than those considered as critical. Under these conditions, the most remarkable histological alterations observed during the short 3-hour period of exposure investigated were those related to acute inflammatory processes, such as migration of polymorphonuclear neutrophils (PMN) to the lamina propria and congestion. These findings were observed in both groups, but were slightly more intense in the group of animals ventilated via an ET. Perhaps, extending the study period, and consequently the time of mucosa exposure to such conditions, could provide more relevant histological results in the ET group. Inflammation is a complex reaction consisting of vascular responses, migration and activation of leukocytes. Vasodilatation leads to fluid accumulation and leukocyte migration to extravascular tissues under the influence of chemotactic agents. The inflammatory response is essentially a defense mechanism whose primary goal is to eliminate the initial cause of cell lesion and its consequences (tissue repair process). No animal in any of the study groups showed more intense histological damages, such as epithelial hemorrhage and erosion. These findings are more commonly reported in more severe epithelial injuries caused by intubation trauma and in sites where the mucosa is in contact with cuffs ${ }^{13,14}$, but these areas were not examined here.

Scanning electron microscopy most commonly revealed ciliary grouping and disorganization on the epithelial surface in both groups. These alterations, attributed to low inspired gas humidity, may be observed when the mucus is thicker and dehydrated, leading to cilial adherence as described by others authors $^{3}$. In this study, the prevalence of these alterations in the group ET could be attributed to the less favorable conditioning of the gases inspired. However, the analysis of the semiquantitative scores once more demonstrated no significant difference, not allowing the establishment of a causal relationship among variables. In our previous study ${ }^{6}$, significantly higher tracheal air absolute and relative humidity were verified in dogs exposed to the inhalation of high FGF through a LMA (23 mg $\mathrm{H}_{2}$ O.L $\mathrm{L}^{-1}$ and $80 \%$, respectively) than in those ventilated through an ET (14 mg $\mathrm{H}_{2} \mathrm{O} . \mathrm{L}^{-1}$ and $50 \%$, respectively).

The relative humidity of the gas is also important, even if the absolute humidity was sufficient, a low relative humidity of about $50 \%$ dried the secretions and the condensed secretions might stick in the ET of the patients in a critical care unit ${ }^{15}$. Thus, the low relative humidity of the inhaled gas in both groups could to explain the lack of significant differences between the results obtained under SEM in the groups.

Only TEM showed significant differences between groups. The animals ventilated via an endotracheal tube displayed more intense morphological alterations, such as disorganized ciliary positioning, widening of cell junctions, inflammatory cell infiltrates in the epithelium, cytoplasmic vacuolization, and abnormal nuclear morphology including irregular picnotic nuclei with condensed chromatin. The basement membrane seemed normal in all animals. Some of the ultrastructural alterations, such as cytoplasmic vacuolization and changes in nuclear shape, were exclusively observed in the group ET. The inclusion of TEM examination in this study was crucial to detect early tracheal epithelium alterations. Otherwise, these morphological signs of cell suffering and death would not be detected.

Some further limitations of this study need to be discussed. As with any animal model, data cannot be directly transposed to humans. The principal advantage of an animal model is that ensures identical standardized treatments and allows post-mortem histological studies. In the study, we utilized LMA or ET for three hours. However, LMA is usually used for surgery not exceeding $1-2$ hours. This could difficult the extrapolation of our reported results to a realistic clinical scenario. On other hand, the use or a LMA during prolonged surgery is increased ${ }^{16,17}$.

\section{Conclusion}

In comparison with ventilation via an endotracheal tube, the use of a laryngeal mask airway determines less pronounced changes in the tracheal epithelium in dogs exposed to the inhalation of poorly conditioned gases. 


\section{References}

1. Widdicombe J. Microvascular anatomy of the nose. Allergy. 1997;52:7-11.

2. MacFadden ER Jr. Heat and water exchange in human airways. Am Rev Respir Dis. 1992;146:8-10.

3. Bisinotto FMB, Braz JRC, Martins RHG, Gregório EA, Abud TMV. Tracheobronchial consequences of the use of heat and moisture exchanger in dogs. Can J Anaesth. 1999;46:897-903.

4. Turner BS, Loan LA. Tracheobronchial trauma associated with airway management in neonates. AACN Clin Issues. 2000;11:28399.

5. Todd DA, Boyd J, Lloyd J, John E. Inspired gas humidity during mechanical ventilation: effects of humidification chamber, airway temperature probe position and environmental conditions. J Paediatr Child Health. 2001;37:489-94.

6. Dias NH, Martins RHG, Braz JRC, Carvalho LR. Larynx and cervical trachea in humidification and heating inhaled gases. Ann Otol Rhinol Laryngol. 2005;114:411-5.

7. Bisinotto FMB, Braz JRC, Martins RHG. Umidificação dos gases inalados. Rev Bras Anestesiol. 1999;49:349-59.

8. Henriksson BA, Sundling J, Hellman A. The effect of a heat and moisture exchanger on humidity in a low-flow anaesthesia system. Anaesthesia. 1997;52:144-9.

9. Chalon J, Loew DA, Malebranche J. Effects of dry anesthetic gases on tracheobronchial ciliated epithelium. Anesthesiology. 1972;37:338-43.

10. Van Oostdam JC, Walker DC, Knudson K, Dirks P, Dahlby RW, Hogg JC. Effect of breathing dry air on structure and function of airways. J Appl Physiol. 1986;61:312-7.

11. Kleemann PP. Humidity of anaesthetic gases with respect to low flow anaesthesia. Anaesth Intensive Care. 1994;22:396-408.

12. Wada H, Higuchi H, Arimura S. Temperature and humidity of the Drager Cato anesthetic machine circuit. J Anesth. 2003;17:166-70.
13. Martins RHG, Braz JRC, Defaveri J, Gregório EA, Abud TMV. Effect of high laryngeal mask airway intracuff pressure on the laryngopharyngeal mucosa of dogs. Laryngoscope. 2000;110:64550 .

14. Abud TM, Braz JR, Martins RH, Gregorio EA, Saldanha JC, Raiza AC. The Lanz endotracheal tube decreases tracheal injury in dogs. Can J Anaesth. 2005;52:878-82.

15. Miyao H, Hirokawa T, Miyasaka K, Kawazoe T. Relative humidity, not absolute humidity, is of great importance when using a humidifier with a heating wire. Crit Care Med. 1992;20:674-9.

16. Nicholls M. ProSeal laryngeal mask airway use for prolonged middle ear surgery. Br J Anaesth. 2001;87:323-4.

17. Martin Castro MC, Polo C, Bassas E, Benito C, Abejon R, Alcazar T. Combined regional-general anesthesia with use of the Proseal laryngeal mask during prolonged peripheral plastic surgery. Rev Esp Anestesiol Reanim. 2009;56:43-6.

\section{Correspondence:}

Norimar Hernandes Dias

Depto. Oftalmologia, Otorrinolaringologia e Cirurgia de Cabeça e Pescoço

Faculdade de Medicina de Botucatu

Distrito de Rubião Junior

18618-970 Botucatu - SP Brasil

Tel/Fax: (55 14)3811-6256

norimar.dias@fmb.unesp.br

Received: January 14, 2011

Review: March 17, 2011

Accepted: April 19, 2011

Conflict of interest: none

Financial source: none 